\title{
Diabetes in the Chinese Hamster
}

\author{
Some clinical and metabolic aspects* \\ K. Gundersen**, George Yergantan, Bonifade J. Lin, Henry Gagnon, Fred Belu, Wayne McRaf \\ and TroLd ONSBERG
}

The Department of Preventive Medicine, Tufts University School of Medicine, and The Childrens Medical Center Hospital, Medford

\begin{abstract}
Summary. A clinical study of hereditary diabetes in the Chinese hamster has revealed a great variety in severity and course of the disease. Several aspects of the disease in this animal resemble human diabetes, whereas other parameters, such as gross urine volumes and glycosuria, a considerable number of mild juvenile-onset diabetics, high insulin requirement, and ability to compensate for urine losses of fluids and glucose would indicate that species differences in metabolism may be the cause of these discrepancies. - Metabolism in vivo and in vitro of glucose and leucine appears to be slightly different in the normal and diabetic animal, although statistically this has not been proven.
\end{abstract}

Le diabète du hamster chinois: quelques aspects cliniques et métaboliques.

Résumé. Nous avons étudié cliniquement le diabète héréditaire du hamster chinois, et, en particulier, nous avons pu suivre 79 animaux pendant des périodes prolongées. Le diabète chez ce hamster est variable quant à sa sévérité et quant à son évolution clinique. Par plu. sieurs aspects il ressemble au diabète humain, mais il s'en différencie par l'énorme volume urinaire, la fréquence du diabète léger même chez les animaux jeunes, une résistance relative à l'insuline, et une capacité extraordinaire de compensation pour les pertes de liquide et de glucose dans l'urine. Ces différences sont si marquées qu'elles suggèrent l'existence de différences fondamentales entre le métabolisme du hamster chinois et celui de l'homme. Bien que certaines différences aient pu être démontrées dans le métabolisme du glucose et de la leucine entre l'animal diabétique et l'animal normal, la signification statistique de ces différences reste à établir.

Der Diabetes beim chinesischen Hamster: Beobachtungen über Klinils und Stoffwechsel.

Zusammenfassung. Eine klinische Untersuchung des hereditären Diabetes im chinesischen Hamster hat ergeben, daß große Schwankungen in bezug auf die Schwere und den Verlauf der Stoffwechselstörung bestehen. Verschiedene Merkmale der Krankheit in diesem Tier ähneln dem menschlichen Diabetes, während andere Aspekte, wie z.B. Urinmenge und Glykosurie, oder die beträchtliche Anzahl der Tiere mit leichtem jugendlichen Diabetes, der hohe Insulinbedarf und die Fähigkeit größere Urinund Glucoseverluste auszugleichen, darauf hinweisen, daß diese Widersprüche artbedingt sein könnten. In vivo und in vitro durchgeführte Stoffwechselstudien mit Glucose und Leuzin scheinen im normalen und diabetischen Tier leicht zu differieren, obgleich dies statistisch nicht zu beweisen war.

Key-words: Spontaneous Diabetes, Chinese hamster, Cricetulus griseus, Clinical diabetes, Glucose metabolism, Leucine metabolism.
Since hereditary diabetes mellitus was discovered in the Chinese hamster over a decade ago [5] several aspects of the disease have been elucidated in regard to clinical, metabolic, and histological findings. Thus it appeared that the degree of severity ranges as widely as that seen in man, and age of onset had a similar variability. The genetic aspects are equally comparable. Like human diabetes, no standard serum protein pattern can be used for prognostication, although an $\alpha_{2}$-peak for some time was thought to be diagnostic of the disease prior to other clinical findings $[4,2]$.

The only divergencies from human diabetes seem to be an exorbitant excretion of urine accompanied by gross glycosuria, and relatively poor response to large doses of insulin.

Over the past five years, our laboratory has had the occasion to study a relatively large number of diabetic Chinese hamsters and thus has been able to arrive at some conclusions regarding age of onset, degree of

* Supported by USPH Grant Nos AM5203, AM60711, and RS8362.

** Present address: The Upjohn Company, Kalamazoo, Michigan. U.S.A. severity, course of the disease, and age at death. Furthermore, response to insulin, weight fluctuations, and the significance of acetonuria have been followed. $\Delta$ limited effort to produce permanent diabetes with growth hormone and glucocorticoids has been undertaken.

The response in vitro of the hamster diaphragm to insulin has also been studied, both in respect to glucose uptake and leucine incorporation, together with experiments in vivo measuring $\mathrm{CO}_{2}$ production from labelled glucose to search for abnormalities in metabolism, and, if possible, to relate these findings to the clinical status of the animal.

\section{Materials and Methods}

All animals were kept in metabolic cages and received rat pellets ad libitum. Urine volume was measured daily, using toluene as a preservative, and tests for acetone (Acetest tablets) and sugar (Tes-Tape, Clinistix) done together with quantitative Benediat's test when qualitative sugar determinations so indicated. In the past two years, the Autoanalyzer was used, diluting the urine $1 / 5$. The latter two methods 
agreed well. Animal weight was recorded daily in most cases, using a Mettler animal balance. Terramycin was added to the water supply when unexpected weight loss occurred or clinical signs of infection (ocular, testicular, respiratory) were present. This apparently saved the lives of a number of animals, as indicated by weight gain and clinical improvement.

Insulin (NPH or regular U 40) was given subcutaneously in the shoulder or flank. In some cases the insulin was given intraperitoneally.

For respiratory $\mathrm{CO}_{2}$ studies, ${ }^{14} \mathrm{C}$-glucose was injected intraperitoneally ( $1 \mu$ curie dissolved in $1 \mathrm{ml}$ of saline) in the fed state. Both the C-1 and C-6 label were tested at three different times, with $6-7$ days interval between tests. Diabetics were pretreated with 2-4 Units of NPH insulin prior to testing with this drug. Insulin in the diabetics and glucose in the normals $(100 \mathrm{mg}$ in combination with the radioactive glucose in 1 ec saline) were given intraperitoneally just prior to placing the animals in a plastic cylinder 12 inches long and 3 inches in diameter. Outside air was sucked through this eylinder at the rate of $0.5-1$ $\mathrm{L}$ per minute, as measured by a manometer. $\mathrm{CO}_{2}$ was absorbed by passing the air through 5 ec of Hyamine (Packard) in a test tube sealed off from the outside air. A tandem set-up of Hyamine tubes revealed no activity in the second tube. Hyamine was changed every $1 / 2$ hour by change of the tubing to a similar set-up. Each tube of Hyamine was weighed before and after gassing to compensate for loss of liquid during gassing, as stickiness made volume measurements impractical. Residual Hyamine was blown out of the sintered bubbling tube by reverse flow to minimize losses. Aliquots were counted in a scintillation counter (Nuclear Chicago 703), using the toluenePPO and POPOP system. Respiratory ${ }^{14} \mathrm{CO}_{2}$ was calculated as percentage of total dose injected in each $1 / 2$ hour interval.

Studies in vitro of glucose uptake in the hemidiaphragm were done according to previously described techniques [1], and in one experiment ${ }^{14} \mathrm{C}$-leucine was added to the buffer for protein incorporation studies. In this instance glucose uptake was calculated in $\mathrm{mg} \%$ per $10 \mathrm{mg}$ wet diaphragm as the protein extract was plated for planchette counting.

Growth hormone (bovine ${ }^{1}$, ovine ${ }^{1}$, and human ${ }^{2}$ ) was given either daily or every two days in $1-4 \mathbf{~ m g}$ doses subcutaneously over a period from 9-32 days. Cortisone acetate, $10 \mathrm{mg}$, was given subcutaneously only once per animal.

\section{Results}

The normal life span of the Chinese hamster ranges from 2 to 4 years, with an average of about 3 years. In our group of diabetic animals, the age of onset has

1 Supplied by Dr. A. E. Wrrнerm, Emory U., Atlanta, Ga.

2 Supplied by Dr. Maurice Rabeis, New England. Center Hospital, Boston, Mass. been plotted against degree of severity in Fig. 1. Our effort at classifying severity is outlined in Table 1. As can be seen, early onset of diabetes is in general related to a higher degree of severity; and all insulin

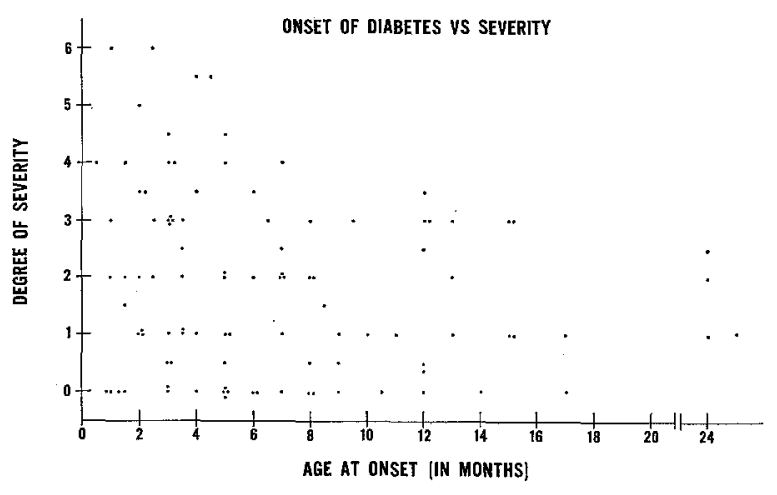

Fig, 1

Table 1. Gradations in severity of diabetes in the Chinese hamster

0 . Sporadic glycosuria

1. Consistent, mild glyeosuria ( $\rightarrow 1 \mathrm{gm} / 24 \mathrm{hrs}$ )

2. Moderate-Gross glycosuria (1-2 gm)

3. Gross glycosuria $(2+\mathrm{gm})$ without acetonuria

4. Gross glycosuria with mild acetonuria

5. Gross glycosuria with consistent, heavy acetonuria

6. Gross glycosuria with consistent, heavy acetonuria, insulin dependent.

requiring animals were discovered within the first few months. However, in a considerable number of early-onset diabetics the severity is surprisingly low. In Fig. 2 similar data for cortisone-induced diabetes are presented. All our animals had relatively mild diabetes regardless of age of induction.

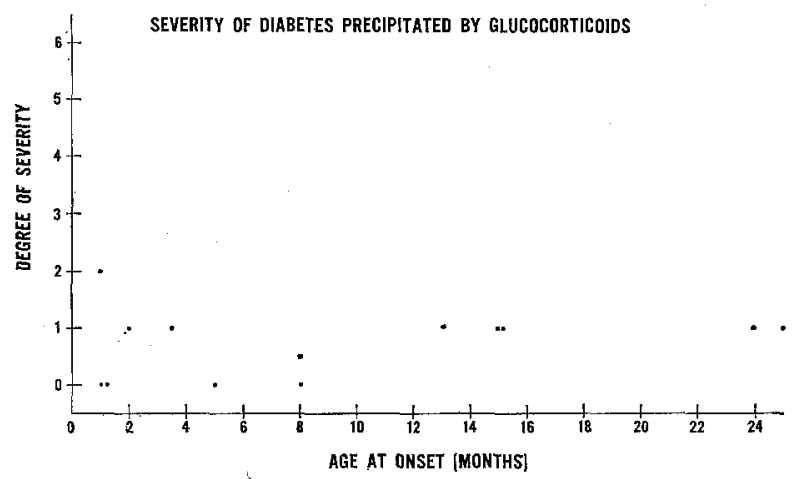

Fig. 2. Onset and severity of cortisone-induced diabetes (permanent glycosuria) in 13 animals

Although most diabetic animals died prior to completion of a "normal" hamster life span, a number of animals survived well into normal range, as seen in Fig. 3. All animals included died a "normal" death. The most severe cases tended to die at an earlier age. Several animals with cortisone-induced diabetes were sacrified, and are thus not included in this figure. 


\section{Growth hormone}

An attempt at inducing the diabetic state with this hormone in animals who had shown occasional glycosuria, and thus should be more susceptible than an aglycosuric animal, showed very poor responses in all but one animal, as indicated in Table 2. Since one

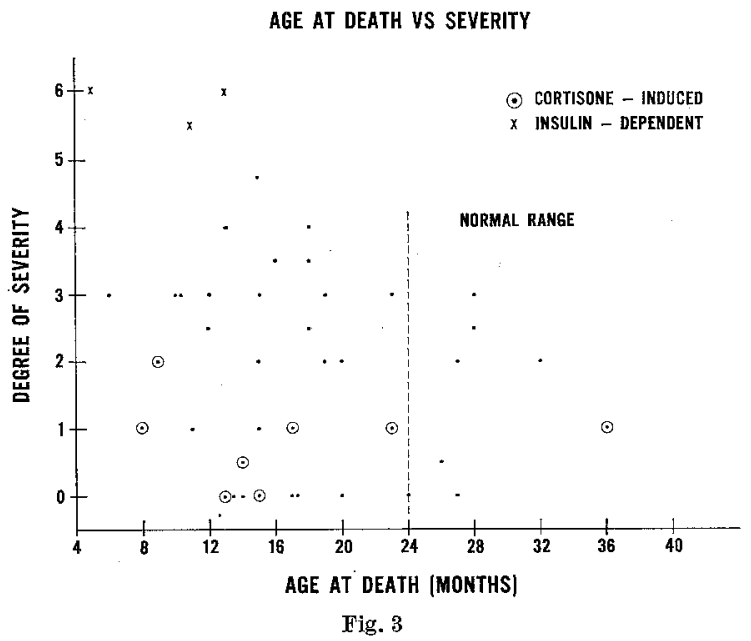

Table 2. Response to growth hormone

Type
Bovine
No glycosuria
1 - 16 day glycosuria

Permanent glycosuria
Ovine
No glycosuria
Human
$\mathbf{1 3}$ day glycosuria

Average weight gain on hormone $12.3 \%$

animal given human growth hormone over a prolonged period developed spontaneous permanent glycosuria two months after cessation of the drug, it is hard to tell even in this case if the bovine growth hormone was the cause of the manifestations. It appears that bovine and human growth hormone were slightly more effective than the ovine preparation. However, all animals on all preparations gained weight equally well, indicating that the hormone has some activity on the animals in spite of the failure to grossly raise blood sugars. A small increase in urine volume (3$10 \mathrm{cc})$ was also seen. Administration of corticoids at a later date seemed to have a more profound effect than growth hormone on urine glucose. In two cases where cortisone was given prior to growth hormone, temporary glycosuria ensued. However, no glycosuria was seen following administration of bovine growth hormone.

\section{Clinical course}

We had the opportunity to study 79 animals over a prolonged period of time. Thirty-one became gradually worse as far as glycosuria and volume of urine were concerned, although the ultimate development of acetonuria was rare. Eight animals had a fluctuating course as far as the above parameters were concerned, twenty remained stable, and twenty became definitely better with time, usually spontaneously, and usually with a concomitant weight loss of $3-6$ grams. One animal with gross glycosuria ceased to have any sugar in the urine after one injection of 4 units of NPH insulin.

Gross acetonuria occurred in twenty animals (thirteen females and seven males) and was usually associated with weight gain just prior to onset. Most animals had acetonuria immediately after diagnosis, although three animals developed this sign after $1-3$ months. One animal had spontaneous remission of acetonuria after one month. All the other animals responded promptly to insulin, with cessation within a day or two. Three animals, all males, needed daily insulin injection to maintain weight and to keep glycosuria and urine volumes at more reasonable levels. In most animalls acetonuria would recur in $3-5$ days when insulin was stopped. Juvenile diabetics gained weight well with insulin given at intervals of 1-4 days, although moderate acetonuria and often gross glycosuria was present. Many animals had little or no decrease in glycosuria with 1-2 units of insulin, but doses between 4 and 6 units a day eventually resulted in marked decreases both in volume and grams of glucose excreted. The more severe the glycosuria, the less pronounced was the effect of insulin, and it appeared as if antagonistic factors were present, with a delayed response in every severe case. Animals with milder glycosuria usually responded promptly to 1-2 units of insulin, and several of these animals were obviously suffering from hypoglycemia. Two animals died in hypoglycemia, one a few hours after an intraperitoneal injection of crystalline insulin. It is possible that some of the more severely diabetic animals had poor absorption of subcutaneous doses of insulin due to poor fat stores, but even two daily intraperitoneal injections had little effect, again suggesting that other factors were involved.

Table 3. Weight changes in diabetic hamsters

\begin{tabular}{llll}
\hline & \multicolumn{3}{l}{ Age in months } \\
\cline { 2 - 4 } & $\mathbf{1 - 6}$ & 7 or more & Total \\
\hline No. with weight loss & 16 & 10 & 26 \\
No. with stable weight & $\mathbf{3 4}$ & $\mathbf{1 2}$ & $\mathbf{4 6}$ \\
No. with weight gain & 13 & 6 & $\mathbf{1 9}$
\end{tabular}

Among 91 animals an evaluation of weight fluctuations showed the changes reported in Table 3 . In each case weight at death was compared with weight at onset of diabetes. The proportion of weight loss was higher after six months of diabetes. Since a number of diabetics were still growing at the onset of the 
disease, a fairly large number showed weight gains of 4 to 20 grams. Maintenance of weight was seen in a large number of animals, and even in grossly glycosuric animals weight was maintained, accompanied by a voracious appetite. Most animals who showed weight loss also showed amelioration of the diabetes. A few animals lost weight just prior to death and

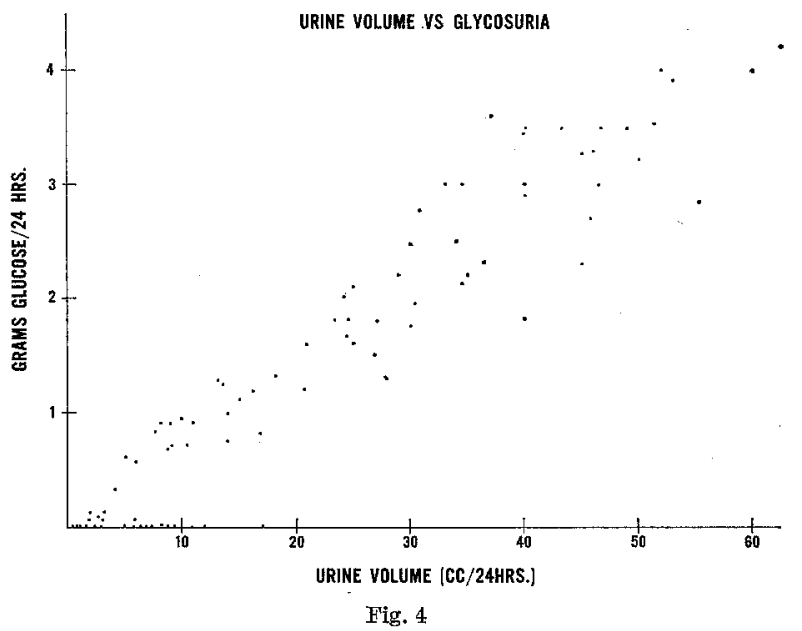

is apparent. All normal animals excreted less than $3 \mathrm{ml}$ of urine per 24 hours except for the ones included in this figure. In these animals there seemed to be a

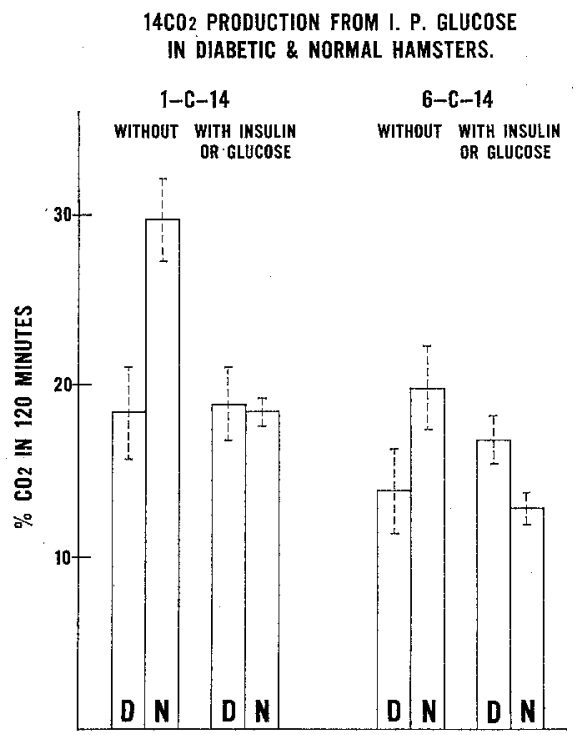

Fig. 5

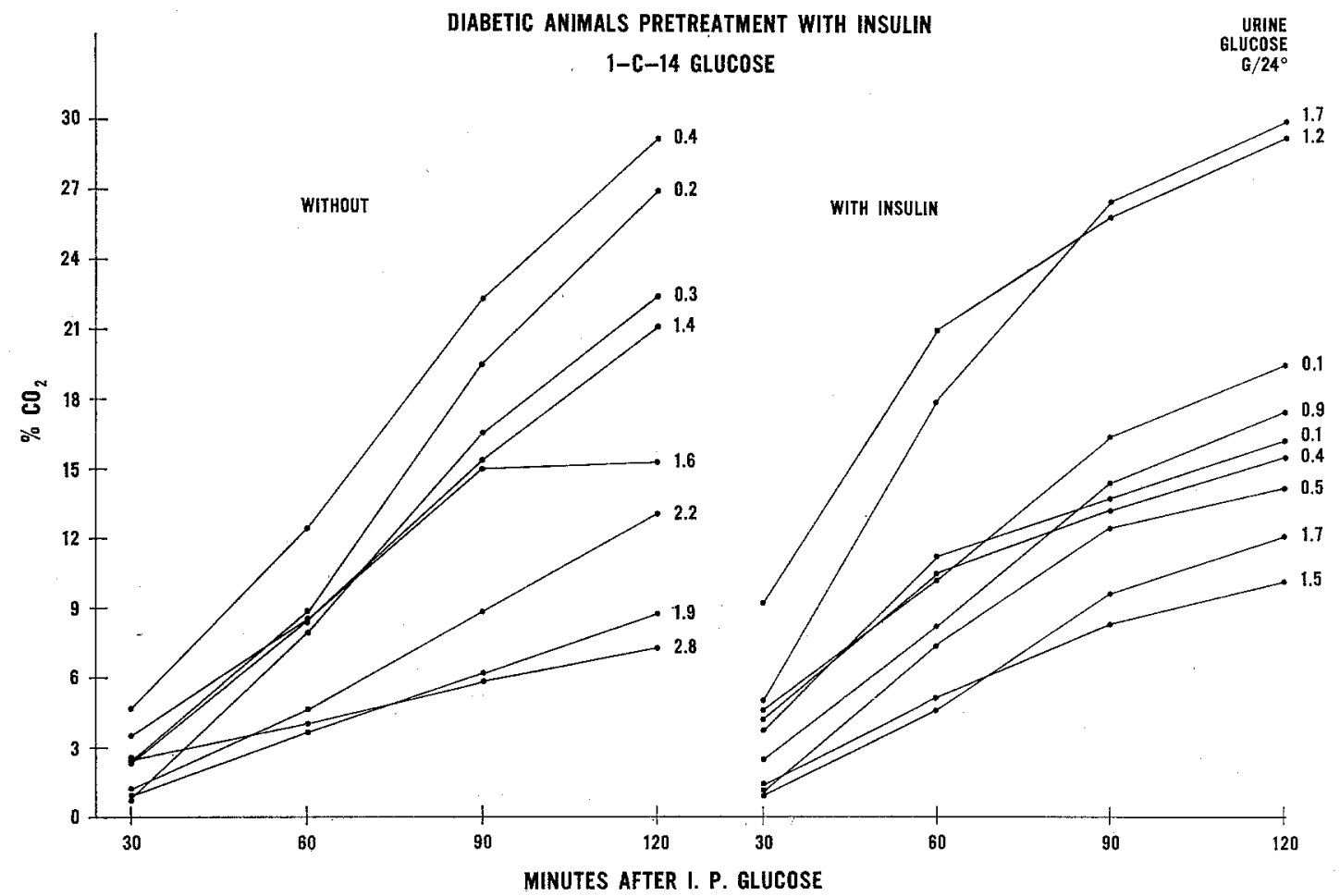

Fig. 6. $\mathrm{CO}_{2}$ production in diabetes animals after i.p.injection of ${ }^{14} \mathrm{C}-1$-glucose with and without pretreatment with insulin. Note that in most cases $\mathrm{CO}_{2}$ output is inversely related to degree of glycaemia

appeared to be sick. Small doses of insulin at this point had no effect on their course. Normal adult animals showed little or no change in weight during life.

An effort was made to correlate urine volumes and glycosuria, as shown in Fig. 4. A fairly close relationship between volume and grams of glucose per 24 hours tendency to polyuria that was not associated with glycosuria, and they never became diabetic.

In vivo respiratory $\mathrm{CO}_{2}$ from injected ${ }^{14} \mathrm{C}$ glucose

As can be seen in Fig. 5, ${ }^{14} \mathrm{C}-1$-glucose seemed to be metabolized to $\mathrm{CO}_{2}$ faster than the ${ }^{14} \mathrm{C}$-6-glucose, 
although the overlap in the diabetic group makes the difference insignificant statistically. Pretreatment with insulin for five days seemed to have no influence
In vitro response to insulin

Table 4 lists the responses of hemidiaphragms from fasted normal and diabetic hamsters. Differences

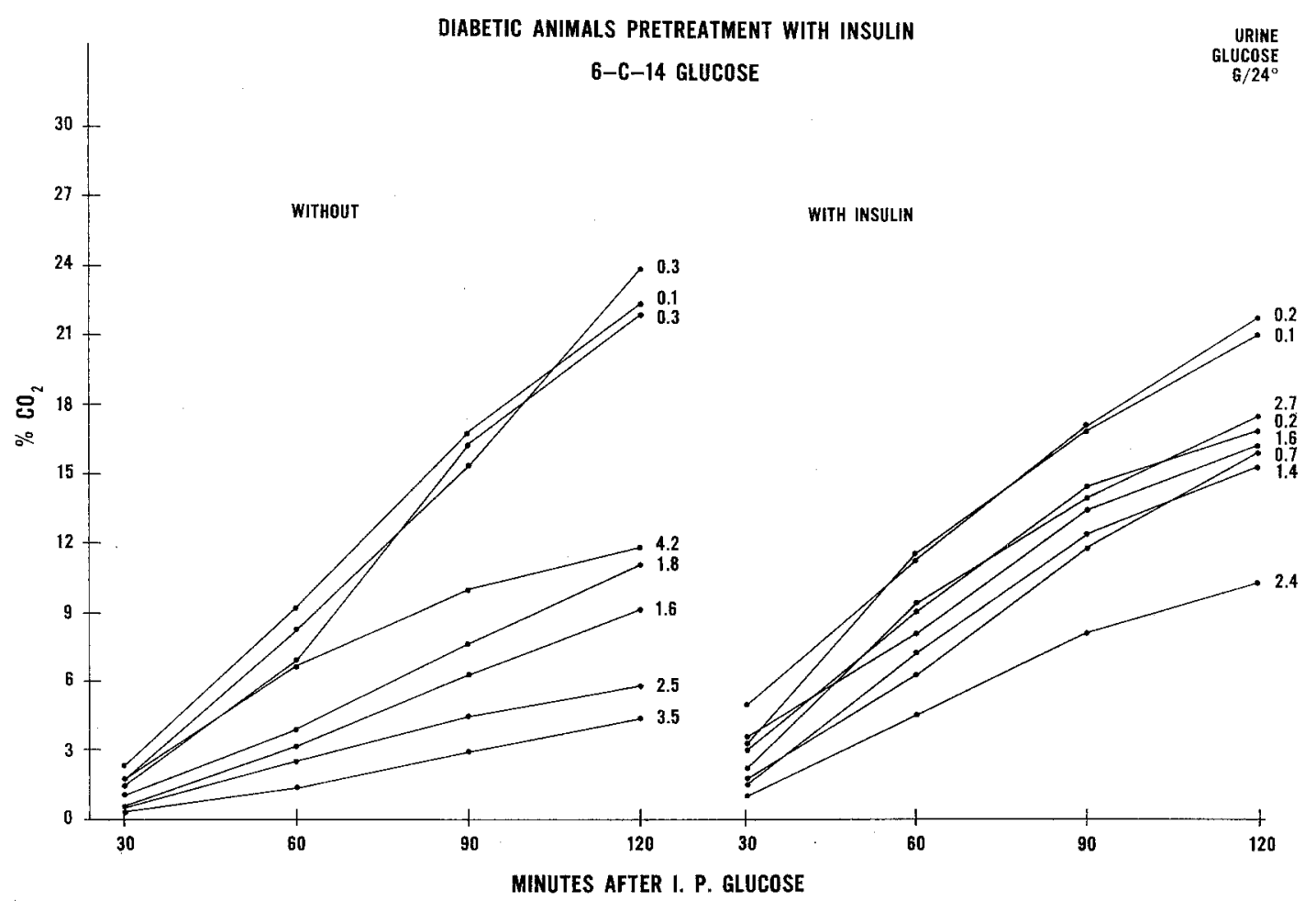

Fig. 7. $\mathrm{CO}_{2}$ production in diabetic animals after i.p. injection of ${ }^{14} \mathrm{C}-6$-glucose with and without pretreatment with insulin

on $\mathrm{CO}_{2}$ production when ${ }^{14} \mathrm{C}-1$-glucose was used, and this in spite of a lowering of glycosuria, as seen in Fig. 6. The only striking changes were seen in the two animals with the lowest $\mathrm{CO}_{2}$ output without insulin. They are represented on the right side by the two high figures. As a whole, administration of insulin to the diabetics, and glucose to the normals, caused both groups to produce $\mathrm{CO}_{2}$ at the same pace (Fig. 5). Administration of insulin caused a statistically insignificant rise in $\mathrm{CO}_{2}$ output when ${ }^{14} \mathrm{C}$-6-glucose was used, whereas the administration of glucose to the normal animals appeared to lower $\mathrm{CO}_{2}$ production significantly from the diabetics. One diabetic animal given ${ }^{14} \mathrm{C}$-6-glucose (Fig. 7) had the lowest output of $\mathrm{CO}_{2}$ without insulin, and showed more than 6-fold increase in $\mathrm{CO}_{2}$ production after insulin, although the change in glucose excretion per 24 hours only diminished from 3.5 to 2.7 grams. Another animal excreting 4.2 grams without insulin had no change in $\mathrm{CO}_{2}$ production with insulin, although glucose output was reduced to 1.4 grams per 24 hours.

Some of the normal animals had a surprisingly low $\mathrm{CO}_{2}$ output (Fig. 8 and 9). This might indicate that they were not completely normal. It should be emphasized that to exclude variations in response each animal had three determinations on different days. None of these animals later showed glycosuria.
Table 4. Glucose uptake on the Chinese hamster with and without insulin in vitro $(1000 \mathrm{U} / \mathrm{ce})$

\begin{tabular}{|c|c|c|c|}
\hline & \multicolumn{2}{|c|}{ Glucose uptake (mg\%/10 mg dry diaphragm) } & \multirow[b]{2}{*}{$\Delta$} \\
\hline & $\begin{array}{l}\text { without } \\
\text { insulin }\end{array}$ & $\begin{array}{l}\text { with } 1000 \mu \mathrm{U} \\
\text { insulin }\end{array}$ & \\
\hline \multirow[t]{3}{*}{ Normal } & $\begin{array}{l}30.4 \\
23.8\end{array}$ & $\begin{array}{l}40.6 \\
33.8\end{array}$ & $\begin{array}{l}10.0 \\
10.0\end{array}$ \\
\hline & $\begin{array}{l}40.0 \\
28.2 \\
27.3\end{array}$ & $\begin{array}{l}64.3 \\
37.0 \\
48.7\end{array}$ & $\begin{array}{r}24.3 \\
8.8 \\
21.4\end{array}$ \\
\hline & $\begin{array}{l}39.4 \\
43.8\end{array}$ & $\begin{array}{l}45.1 \\
52.8\end{array}$ & $\begin{array}{l}5.7 \\
9.0\end{array}$ \\
\hline
\end{tabular}

$\begin{array}{llll}\text { Average } & \overline{32.3} & \overline{46.0} & \\ & & \text { Severity }\end{array}$

\begin{tabular}{rlllr} 
Diabetic & 16.9 & 26.9 & 1 & 10.0 \\
& 28.1 & 47.5 & 1 & 19.4 \\
& 19.4 & 30.8 & 2 & 11.4 \\
& 18.6 & 39.9 & 2 & 21.3 \\
& 18.8 & 39.5 & 3 & 19.7 \\
-11.8 & 31.3 & 2 & 19.5 \\
& $27.3^{1}$ & 37.0 & 3 & 9.7 \\
& 29.6 & 46.3 & 5 & 16.7 \\
\hline 28.2 & 41.3 & 3 & 13.1 \\
\hline $39.6^{2}$ & 48.1 & 2 & 8.5 \\
Average & $44.2^{2}$ & 43.0 & 4 & -0.8 \\
& $\mathbf{5 8 . 6 ^ { 2 }}$ & 63.0 & 4 & 4.4 \\
\hline
\end{tabular}

${ }^{1} 4 \mathrm{U}$ of NPH insulin given 9 days before sacrifice. $24 \mathrm{U}$ of NPH insulin given 4 days before sacrifice. 
between the two groups are not statistically significant. Three assays are included, as indicated by horizontal lines. Unfortunately, an insufficient number of normal more $\beta$ cells. The inordinate excretion of urine and gross amounts of glucose certainly differ quantitatively from human diabetes, and the ability of the animal

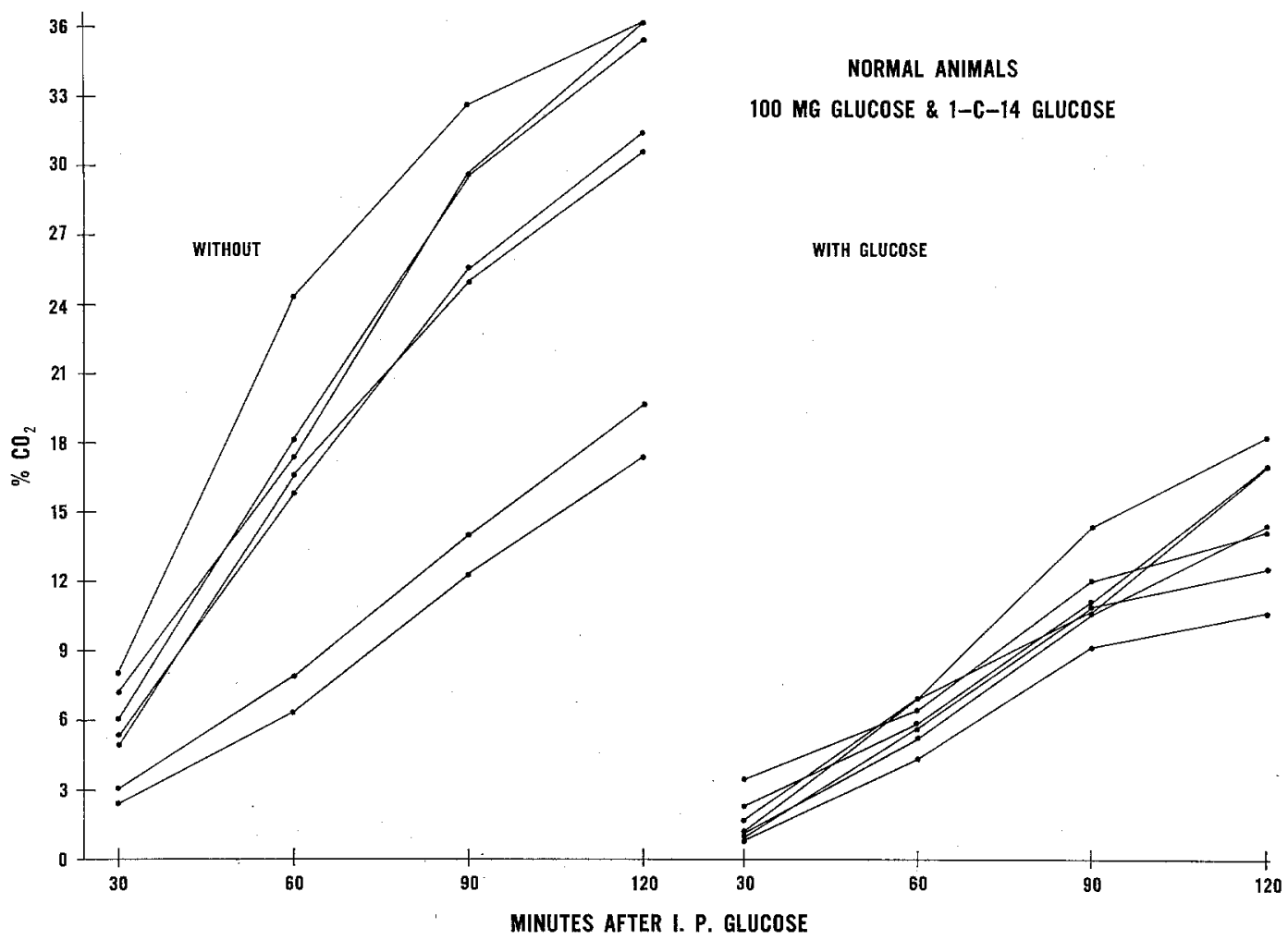

Fig. 8. $\mathrm{CO}_{2}$ production in normal animals after $\mathrm{i}$.p. injection of ${ }^{14} \mathrm{C}-1$-glucose. Note uniform fall in $\mathrm{CO}_{2}$ output when $100 \mathrm{mg}$ of carrier glucose was added

animals were available for the first and third assays. There may be a smaller response to insulin in the more severely diabetic animals, although the baseline uptake without insulin seems to be raised and could be responsible for the discrepancy. There is also a possible influence of previously injected insulin on the basal uptake in $\mathbf{4}$ animals, which may also have influenced the effect of insulin added in vitro.

Table 5 shows glucose uptake and leucine incorporation in five normal and five diabetic animals, together with the blood sugar at time of death. Animal number 1 in both groups showed enough divergencies to warrant no conclusions statistically, although the net difference in leucine incorporation with and without insulin does show a statistical difference, indicating less response to insulin in the diabetic group.

\section{Discussion}

Our observations indicate that diabetes in the Chinese hamster shows similarities to human diabetes, but it is difficult to ascertain whether the dissimilarities can be accounted for only by species difference. Thus early onset and a benign degree of the disease, with no exacerbation, is hardly even seen in man, indicating greater pancreatic reserve, or an ability to produce
Table 5. Glucose uptake ( $\mathrm{mg} \% / 10 \mathrm{mg}$ wet wt) and leucine${ }^{14} \mathrm{C}$ incorportion $(C P M / m g d r y w t)$

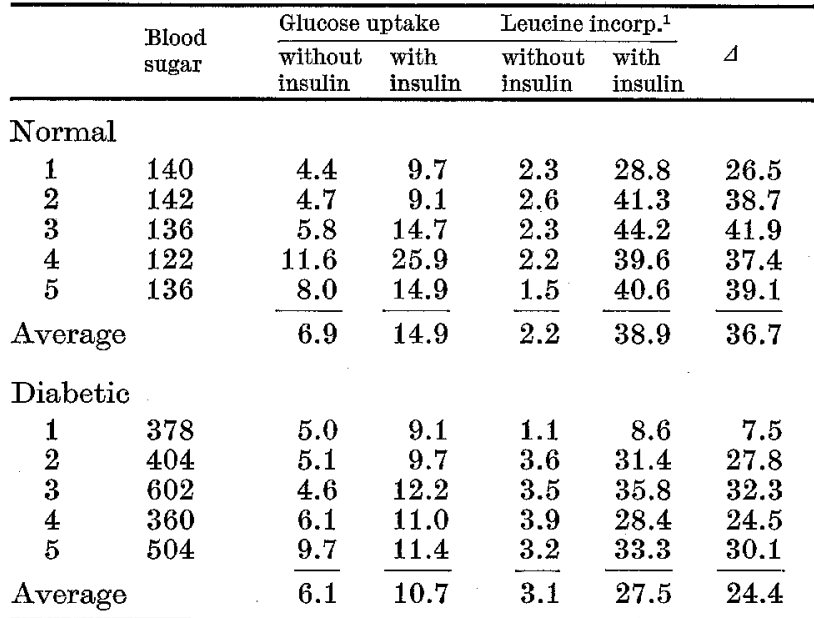

\footnotetext{
${ }^{1}$ Data obtained in collaboration with Mr. STEPEN
} GrassmanN.

to compensate for these losses is not seen in man. Our animals were allowed to eat freely and may thus have shown more glycosuria than animals on restricted food intake (5). However, even with this gross loss of 
liquid and glucose, no significant weight loss took place in most cases.

The amounts of insulin needed for control were at least 100 times human requirements, and even in milder cases large amounts seemed to be necessary, although a prompt response was more evident. It is possible that this animal would respond better to hamster insulin. Response to tolbutamide in mildly diabetic animals has been reported to be similar to that seen in man, indicating that quantitative aspects resemble those seen in human diabetes. The weight spurt seen at times prior to exacerbation of the disease also indicates similarity. that are perfectly "normal" as far as carbohydrate metabolism is concerned, and a true comparison thus becomes virtually impossible.

\section{References}

[1] Antoniades, H.N., and K. Gundersen: Studies on the state of insulin in blood: Materials and methods III. Endocrinology 70, 95 (1962).

[2] Gerritsen, G.C., and W.E. DuLin: Serum proteins of Chinese hamsters and response of diabotics to tolbutamide and insulin. Diabetes 15, 331-335 (1966).

[3] - Characterization of diabetes in the Chinese hamster. Diabetologia 3, 74-84 (1967).

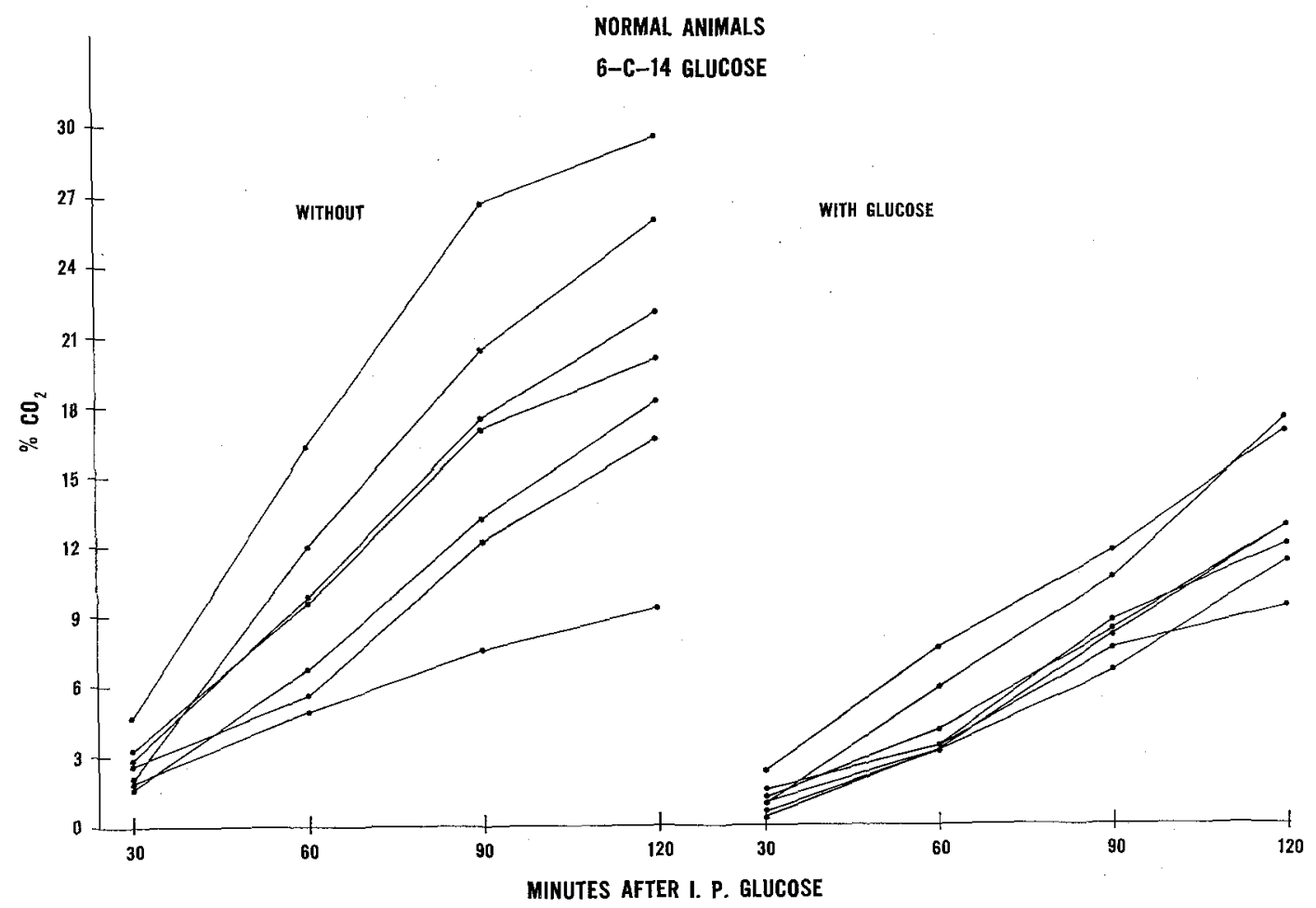

Fig. 9. $\mathrm{CO}_{2}$ production in normal animals after i.p. injection of ${ }^{14} \mathrm{C}-6$-glucose. A similar drop with addition of carrier glueose is seen

Studies of $\mathrm{CO}_{2}$ production indicate a possible quantitative difference in utilization of glucose, but are inconclusive. Similarly, the response of the hamster diaphragm to insulin in vitro in fed animals indicates quantitative changes, but again no definite answer could be obtained because of the limited number of animals. It is doubtful whether such small changes could account for the apparent resistance to insulin. However, since the Chinese hamster in this country is highly inbred, it may be difficult to identify animals
[4] Green, M.N., G.A. Yerganian, and H. MEIER: Elevated $\alpha-2$ serum proteins as a possible genetic marker in spontaneous hereditary diabetes mellitus of the Chinese hamster (Cricetulus griseus). Experientia 16, 503-504 (1960).

[5] Meiter, H., and G.A. Yerganian: Spontaneous hereditary diabetes mellitus in Chinese hamster (Cricetulus griseus). I. Pathological findings. Proc. Soc. exp. Biol. 100, $810-815$ (1959).

Dr. K. GUNDERSEN

The Upjohn Company

Kalamazoo, Michigan, U.S.A. 